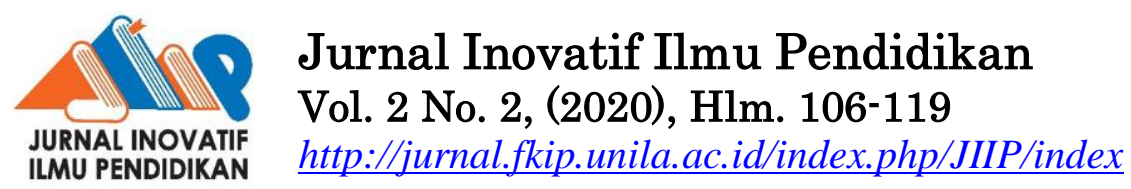

\title{
Accompanying Students in Online Learning: Challenges and Interventions
}

\author{
Gilbert S. Arrieta ${ }^{1}$, Reuben C. Calabio ${ }^{2}$, Elna M. Rogel ${ }^{3}$ \\ ${ }^{1}$ Don Bosco Technical Institute, Makati City, Philippines \\ ${ }^{1}$ Philippine Normal University, Manila, Philippines \\ ${ }^{2}$ Don Bosco Technical Institute, Makati City, Philippines \\ ${ }^{3}$ Don Bosco Technical Institute, Makati City, Philippines \\ Chino Roces Ave, Makati, 1230 Metro Manila, Filipina \\ E-mail: gsarrieta@one-bosco.org
}

Article Info
Received Agustus 2020
Accepted September 2020
Published Oktober 2020

Keywords:

conflicts, learners, online

learning,

difficulties in virtual

learning,

students

learning

\begin{abstract}
When children come to school, parents endorse them to the teachers and staff who have the duty to take care of their formation and growth while they are in school. Being in school does not only allow the students to learn formally but also to meet new people who become their classmates and friends. The home and school which are the primary places of children/students should be nurturing environments where they grow and assisted. In school, the systems are already in place in terms of teaching and learning including the emotional assistance to students. However, this remains to be seen in a virtual learning environment. The Covid-19 pandemic forced teaching and learning to be conducted in an online environment, a road less traveled in education. Though the learning continuity plan was developed and directives were issued, it was expected that there will be challenges and concerns that will emerge. Managing the challenges experienced by the students is another concern. This study aims to find out the difficulties and challenges encountered by the students as shared and observed by the teachers, and how the students were assisted by the teachers. Based on the findings, it was found out that overload of requirements, time management, isolation, and lack of privacy are the main challenges and concerns encountered by the teachers. According to the teachers and guidance counselors, these were managed by being available online to the students, coordination of the student affairs, teachers, and guidance counselors, listening, and counseling/giving of advice. From these findings, the challenges and concerns will be addressed appropriately and lesser concerns will emerge as the online learning progresses.
\end{abstract}

C2020 Jurusan Ilmu Pendidikan, FKIP Universitas Lampung 


\section{INTRODUCTION}

School is the second home of children because it is where they learn and spend most of their time particularly during weekdays. Students meet teachers and classmates who become important part of their lives. They consider their teachers as second parents and classmates as family. A strong relationship is created because they share about their life most especially their struggles and difficulties.

Teachers are influential people in the lives of students. They are admired, appreciated, and idolized because of their impact and animating presence. The quality of presence-a state of alert awareness, receptivity, and connectedness to the working of both the individuals and the group in the context of the learning environment-is unfortunately not often taught explicitly in teacher education programs. Teachers know they have presence when they have a genuine connection with the students that breeds confidence and respect throughout the classroom, allowing for risk taking and increased learning opportunities. These teachers engage in authentic relationships with students, addressing their academic and emotional needs while being resourceful about anticipating unknowns (Henik, 2018). It is always perceived that high school teachers are remembered not only because of the subject that they teach but more importantly the life lessons, advice, and listening ears they lend to their students.

Being with the students outside classes requires time and effort. During recess, lunch break pr even after classes, students would approach their teachers for different reasons. Though mostly the reasons are about their classes, some talk to their teachers and guidance counselors about their personal life. If the teachers and guidance counselors sensed or learned that a student has a problem, they would go out of their way to see and talk to him. Teachers and guidance counselors collaborate to guide and assist the students in their academic and personal life through appropriate interventions. In a private Catholic school in Manila, this is contextually called "animating presence" which strongly supports the preventive system of education. Through the animating presence of the faculty, students' problems and concerns are addressed immediately. In fact, there are intervention programs like the homeroom and guidance activities to assist the students. 
Barely two weeks into Term 3 of school year 2019-2020, classes had to be suspended and cancelled eventually due to the COVID-19 pandemic. Caught unprepared and with no specific modality like synchronous classes to be conducted, the rest of the school year had to be continued through different online platforms. Teachers and guidance counselors reached out and kept in touch with students through facebook, messenger, email, mobile phone, and landline phone. Requirements had to be lessened and considerations were given due to the unlikely situation and condition of the students. Having been familiar and comfortable in animating the students in face-to-face classes, teachers and guidance counselors were groping in the dark in communicating with the students. If there will be a well-established communication system, it will enable all stakeholders to participate and support in the new mode of teaching and learning (Arrieta, 2020).

The experiences of the faculty including the guidance counselors in assisting the students in Term 3 served as the bases in crafting the intervention program for the new learning modality in school year 2020-2021. Immediately after the end of school year 2019-2020, the office of the student affairs initiated a series of discussions with guidance counselors and selected teachers about the programs and activities. In anticipation of the anxiety that online learning may cause, online counseling, "kamustahan (reaching out)", online presence, homeroom and guidance activities, activation of interim student council, and adviser's time are the major initiatives and interventions to accompany the students.

Everything was in place before school year 2020-2021 started. As planned, the programs and activities were implemented with the support of all faculty members particularly the class advisers. During meetings with the different stakeholders, various issues and concerns were raised particularly on students' behavior and their physical and mental welfare. Since no one has been here before, there are challenges that continue to emerge that need to be addressed through various interventions. The experiences and observations of the high school faculty members particularly the class advisers, guidance counselors, and academic council in online teaching and learning last Term 1 will provide significant information and inputs to enhance the intervention programs in accompanying the students. This study aims to identify the challenges and 
difficulties experienced by the students and how the teachers and guidance counselors assisted the students in handling them. The findings will be used to develop an enhanced program and modify policies that will ensure a healthy and sound virtual learning environment for the students.

The following are the research questions for this study:

1. What are the difficulties and concerns encountered by the high school students in online learning?

2. How did the teachers and guidance counselors address and handle the challenges?

\section{METHODOLOGY}

To know the difficulties, concerns, and challenges experienced by the class advisers and guidance counselors in accompanying the students in online learning particularly in the new normal which is considered a global phenomenon, phenomenological method is used in this study. Phenomenology is an approach to qualitative research that focuses on the commonality of a lived experience within a particular group. The fundamental goal of the approach is to arrive at a description of the nature of the particular phenomenon (Creswell, 2014).

Since school year 2020-2021 started particularly between September and October, the class advisers and guidance counselors were regularly observed, interviewed and met as one group. All of them never experienced this kind of learning modality. Twenty-eight (28) participated in this study.

Experts in educational management, and guidance and counseling were asked to validate the interview questions. The questions were (1) What are the struggles and difficulties (excluding internet connection and technological resources) shared by junior high school students in online learning? (2) How did you assist the students in handling problems of our students in online learning?

To analyze the data gathered in the study, coding was used by the researchers. In coding, the researcher organizes data collected into segments and assigns a word or phrase to them as labels (Creswell, 2014). The researchers sought the permission of the principal and learning area head before conducting the study. The purpose of the study was discussed to the academic heads, class advisers, and guidance counselors. It was made clear that their responses will 
not affect their status in school and will be used to provide quality intervention program and activities to students in online learning.

\section{RESULTS AND DISCUSSION}

1. What are the difficulties and concerns encountered by the high school students in online learning?

Before the start of online classes, school heads and teachers planned for the unknown learning environment which included anticipated issues and concerns. However, despite the planning, there were difficulties and concerns which emerged based on the experiences of the students as observed and perceived by the class advisers and guidance counselors. The issues and concerns encountered by the students in online learning can be gleaned in Table 1 .

Table 1

\section{Difficulties and Concerns of Students in Online Learning}

\begin{tabular}{lll}
\hline Difficulties and Concerns & $f$ & Rank \\
& & \\
\hline Overload of requirements & 24 & 1 \\
\hline Time Management & 14 & 2 \\
\hline Feeling Isolated & 13 & 3 \\
\hline Lack of Privacy & 10 & 4 \\
\hline
\end{tabular}

\subsection{Overload of Requirements}

As shared by the students to their class advisers and guidance counselors, having too many requirements is the most serious concern that students experienced during the first three months of online classes. They felt that accomplishing the voluminous requirements is impossible considering their limited resources. While they thought that the requirements can be easily done because of the internet, they found out that it was more difficult. There was an avalanche of requirements as term 1 progressed. Though classes are only halfday everyday, they find the requirements very overwhelming. Some requirements are not easy to accomplish. Due to this, a significant number of students failed to submit the requirements on time. In a study on accomplishing online requirements, it was revealed that students found online learning 
interesting and they were interested in the class discussion. However, many students failed to submit the requirements on time (Arrieta, 2020).

A guidance counselor shared that:

"According to the students, they were drowned with the unexpected number of requirements. They didn't know which to prioritize. The requirements were just too many."

\subsection{Time Management}

Though many students were able to submit all the requirements before the end of the term, it was found out students lack time management. The first deadline set by the teachers have to be changed because few students submitted on time. Students were complaining that aside from having too many requirements, they were also difficult. They didn't have sufficient time to accomplish them. However, when teachers reset the deadline, a significant number of students failed to submit on time. Based on their observations, the teachers said that there are many distractions at home and in the online environment which prevent students from focusing and doing the tasks. A study showed that in the knowledge society determined by ICTs, where it is very easy to get distracted, managing time efficiently becomes a necessity not only at the university but also in the workplace, reason why it is essential to teach these skills to the students in order to prepare them for the optimal development of their activity in the professional world. The knowledge society has changed our relationship with knowledge and therefore the way of learning and teaching. In this new scenario, the university faces the challenge of teaching students to think and analyze, a lifelong learning, and not only transmit knowledge related to a specific area. The students must be prepared for avoiding procrastination, establishing priorities, planning and organizing multiple tasks, etc., employability skills fundamental in order to be ready for the work market (Sainz, Ferrero, and Ugidos 2019).

A teacher shared the experience of his/her students.

"The time given to them to finish their tasks are not enough. Considering also the difficulty of the requirement, it was not possible for them to submit them on time." 
Another teacher said that:

"There are requirements that can be done on time. It's just that there are too many distractions at home. One of them is being hooked in online games and other online activities that take a lot of their time."

\subsection{Feeling Isolated}

As digital natives, students are always hooked up with gadgets and connected online. They enjoy and spend a lot of their free time playing online games alone or with others. However, online learning which appeared to be interesting to them for a month or two has made them lonely. They miss the school, their friends and classmates. The new normal in teaching and learning brought a feeling of isolation. This is validated by a study when a university experienced high dropout rates in online learning. It suggests that students feel disconnected and isolated from their course, feelings which have been attributed to the physical separation of students from each other and the instructor (Phirangee and Malec, 2017).

A teacher shared the sentiment of his/her students in missing face-to-face classes.

"The absence of the physical presence of teachers, classmates, and friends made them feel that they are alone. They know that they are virtually there but in reality they are not there. There were times that they feel helpless most especially in accomplishing tasks."

\subsection{Lack of Privacy}

Attending classes in school is far different from attending classes at home. Students are used to doing their assignments at home and not attending online classes. Most students felt that they did not have the needed privacy in order to concentrate in their online classes. In one room or area in the house, two or three children are attending classes at the same time. Some have parents watching or attending classes with them which made them feel uneasy and distracted. Students need to have a good learning space at home so that they 
will be able to focus in their synchronous classes and accomplishment of assignments. Some students consider their learning environment inappropriate. Children need a functional spot that minimizes distraction and can set the structure for focused online learning, while giving them both the physical and mental space to get their school work done. Whether you are carving out space in a bedroom corner or taking over the dining table, we've got ideas to help you create a functional place for school work, with a focus on making the most out of whatever room you have (Randazza, 2020).

A teacher and guidance counselor pointed out a concern at home by students. They said that :

"Their individual set-up at their respective houses is challenging. Most of the time, they choose not to speak or share ideas in an online class because someone in their house might be listening to them especially when sharing thoughts about family, opinion, or personal thoughts."

Based on the assessment of the teachers, the difficulties and concerns were anticipated and were prevented. However, there were some which are unanticipated like overload of requirements and time management. The overload of requirements was overwhelming that also caused another concern which is time management. When the difficulties and concerns were discussed, immediate and appropriate actions were taken for they were not impossible to resolve.

2. How did the teachers and guidance counselors address and handle the challenges?

The learning continuity plan (LCP) indicated programs of the school in the conduct of online classes. The LCP is based on the experiences of teachers when they conducted online teaching and learning in the last three months of school year 2019-2020. Though the challenges were anticipated, it was different when online learning was already taking place. Teachers and students a lot of difficulties but the teachers had to take a more active role in handling the challenges encountered by the students. It can be gleaned in Table 2 what the faculty did in managing the challenges experienced by the students. 
Table 2

Managing Students' Challenges in Online Learning

\begin{tabular}{lll}
\hline Actions & $f$ & Rank \\
& & \\
\hline Online Availability of Teachers & 25 & 1 \\
\hline $\begin{array}{l}\text { Coordination of Student Affairs, Class Advisers, } \\
\text { Teachers and Guidance Counselors }\end{array}$ & 17 & 2 \\
\hline Listening & 16 & 3 \\
\hline Counseling/Giving of Advice & 15 & 4 \\
\hline
\end{tabular}

\subsection{Online Availability of Teachers}

A strong part of the school culture since it was established in 1954 is the animating presence of religious and teachers among students. Teachers appreciate and embrace the educational principle of accompanying students particularly outside the classroom. The visibility and availability of teachers including the administrators and principal in campus for informal talk or consultation are appreciated by parents and students. In fact, in a study on visibility in school, it was found out that teachers revealed that the principals often maintain high visibility in schools. They assist teachers who need help in classroom management, make rounds during class hours and take time to talk to students and teachers (Arrieta, Ancho, Pineda, and Carandang, 2020). When the Covid-19 pandemic came and online classes became the learning modality, one of the concerns was on how to assist the students. Eventually, online communications system was established and privacy of teachers and students was secured. Teachers want to reach out immediately to parents and students should there be any issues and concerns in online classes. It was a commitment from the teachers to be always available online but with limitations so that teachers' personal time is respected.

A teacher shared his/her experience on a program that the teachers particularly the class advisers and guidance counselors are doing.

"By creating / co-creating a program like "Online Kamustahan (Reaching Out)" where the students can share their feelings, thoughts and experiences on online learning and their currents home situation, we are able to know their situation." 
2.2. Coordination of Student Affairs, Class Advisers, Teachers, and Guidance Counselors

If the teachers and the other members of the department will not act as one, more problems will be experienced and teachers will be overwhelmed of the challenges faced by the students. Through the office of the student affairs, a system was created to ensure that efforts in assisting the students are coordinated. Whoever gets the information about students' difficulties and concerns, they are reported to the assistant principal for student affairs who initially handles the situation. Appropriate action is taken by asking the guidance counselor or the prefect of discipline to address the concerns. In the new normal particularly in online modality, school leaders must initiate a systemic approach. In a study on school leadership in the new normal, it was found out that students and teachers may encounter issues related to interfacing, behavior, mind-set, and outlook. A school leader brings the best in this biggest challenge: a humane teaching and learning experience primarily employing digital technology. Lastly, a proactive and genuine partnership between schools, stakeholders, and linkages could spark initiatives in taking steps towards success in the academic experiences of the students. Stakeholders and linkages working hand in hand in the light of the pandemic cements crucial path that contributes to efforts to make teaching and learning a reality despite the health crisis. Together, these stakeholders will succeed as one (Ancho, 2020).

A class adviser shared the coordination among teachers. He/She said that :

"When there are concerns, I immediately talk to the student/s involved and then tell the assistant principal for student affairs and the guidance counselor about the concern. I also share the issues during our regular advisers meeting:"

\subsection{Listening}

Being present and reachable by students is important in the growth of every student most especially in this new normal situation. Students know that teachers are present but listening to their concerns is what they need. Their difficulties on the many school assignments and tasks were addressed because 
their teachers listened to them. Likewise, their problems at home were lessened because of the listening ears and hearts of their teachers.

What's most important, perhaps, is that when you ask students questions, you ask with an open heart and an open mind -- willing to listen to whatever they say, as well as willing to listen for what's not said. Many of our older students have had enough negative experiences in school for them to feel that teachers don't listen to them. This could be the year when you change that for them. Everyone deserves to be listened to, and listening is a powerful way to connect with others (Aguilar, 2016).

In the present time of COVID pandemic, the role of teachers become crucial in pulling out students from the depths of anxiety and stress. Teachers can act as psychological first aid for those facing any emotional challenges. Although, psychological first aid is generally provided by the professional counsellors, in the present precarious circumstances, teachers need to take up this responsibility also to help the students in taking care of their mental wellbeing (Ahmed and Firdous, 2020).

\subsection{Counseling/Giving of Advice}

As second parents, the class advisers, teachers, and guidance counselors ensure that the students are reminded regularly on their behavior and performance in class. During advisers period and homeroom/guidance period, students are provided with information, tips, and encouragement particularly on how to deal with the difficulties and challenges in life. This is also observed during online classes despite the challenges it posed to the teachers. According to the advisers, after listening to their students most especially those with emotional and behavioral problems, they give solicited or unsolicited advise. The guidance counselors provide encouragement and give hope to the students through consistent follow up and conference. The class advisers and guidance counselors believe that technology can be optimized in assisting the students. Their experiences showed that their frequent communication with the students proved to be helpful. A study supports this experience of the teachers and counselors. It revealed that school counselors during the Covid-19 pandemic had challenges in implementing online counselling with individual counseling services and group counseling services. The implementation of counseling 
services for students by school counselors uses technology media as an element of developing the professional competence of school counselors. Professional guidance and counseling teachers can plan, implement, and evaluate themselves in the use of technology media in counseling services. The technology media used are synchronous and asynchronous based. Asynchronous media with WhatsApp, Facebook, Instagram or social media. Sync with Media Zoom, Webex, Google Meetings and Hangouts. It is identification information related to student problems using WhatsApp or Google Form. While the implementation of counselling through technology media is used based on synchronous and asynchronous according to student needs (Supriyanto, Hartini, Irdasari, Miftahul, Oktapiana, and Mumpuni, 2020).

A teacher shared that:

"I talk to them in private usually after adviser's time or synchronous classes.I clarify things about the information given to me by their classmates usually their behaviour in other subjects."

Another teacher shared that :

"I send private messages or chat with them. I also give advice when they ask. Sometimes, I explain how to do things if they don't know how to do it."

The difficulties and challenges were managed through appropriate actions particularly collaboration among teachers and staff in the department. Meetings were held in order to craft and implement policies. The school culture and commitment of the teachers made it possible to address the problems immediately. The teachers continue to be committed and open in making online learning meaningfully despite its limitations.

\section{CONCLUSION}

Online teaching and learning is not new most especially to colleges and universities that offered it as an alternative modality. However, the Covid-19 pandemic forced the education sector to continue through the online and other alternative modalities. Initiated by the Department of Education, all public and private schools prepared a learning continuity plan that will guide all stakeholders. The curricular programs and other policies have to be softened 
and tweaked to make online teaching and learning to take place. For the curriculum, only the most essential learning competencies have to be taught. Some policies like attendance and grading system have to be modified to suit the performance of students in the new normal learning modality.

After one term or three months of online teaching and learning, it can be concluded that there were difficulties and challenges that came out which were not anticipated particularly its impact on the students like overload or requirements and readiness of students in doing requirements in an online environment. As if it will be easy learning at home, the privacy of students and feeling of isolation are concerns that need to be addressed and considered in order for online teaching and learning to happen more effectively.

Teachers agreed that their commitment to make education happen in the new normal proved to be a driving factor to encourage and assist students. They realized that they have to be creative in accompanying and guiding the students in an online environment. With much experience in physical classes, they thought of doing the same thing but in a creative way like using different applications and softwares.

Teachers with a significant meaningful experiences in face-to-face classes and a school with a system and culture on animating presence have become a strong foundation to make education happen more meaningfully in an online environment. The situation may be different but the commitment of teachers and the philosophy of education of the school are both helpful whether the learning environment is physical or virtual.

\section{REFERENCES}

Aguilar, E. (2016). When We Listen to Students. Edutopia. https://www.edutopia.org/blog/when-we-listen-students-elena-aguilar

Ahmed, A., \& Firdous, H. (2020). The Transformational Effects of COVID-19 Pandemic on Guidance and Counseling. International Journal of Advance Research and Innovative Ideas in Education. Vol-6 Issue-6. ISSN (0)-2395, 4396. 
Ancho, I. V. (2020). Old Mind-set, Values and Ethics, and Stakeholder Partnership and Accountability: Inputs to School Leadership in the New Normal. Jayapangus Press Books, 17-32.

Arrieta, G. S. (2020). The Experiences Of Junior High School Teachers In Online Teaching And Learning During Enchanced Community Quarantine: Inputs For The Learning Continuity Plan For The New Normal In Education. Jayapangus Press Books, 383-404.

Arrieta, G. S., Ancho, I. V., Pineda, M. D., Carandang, H. A., \& PF, K. A. P. D. (2020). Assessment Of Principal's Instructional Leadership In Selected Public Schools: Basis For Instructional Development Program. Jurnal Penjaminan Mutu, 6(2), 146-158.

Creswell, J. W. (2014). Research design: qualitative, quantitative, and mixed methods approaches. 4th ed. Thousand Oaks, California: SAGE Publications.

Henik, Sol. (2018). Developing Your Classroom Presence. Edutopia. https://www.edutopia.org/article/developing-your-classroom-presence

Krystle Phirangee \& Alesia Malec (2017). Othering in online learning: an examination of social presence, identity, and sense of community, Distance Education, 38:2, 160-172. DOI: 10.1080/01587919.2017.1322457

Sainz, María Alvarez., Ana M. Ferrero, Ugidos, Arantza. (2019). "Time management: skills to learn and put into practice", Education + Training. https://doi.org/10.1108/ET-01-2018-0027

Randazza, J. (2020). HOW TO CREATE AN AT-HOME WORKSPACE FOR ONLINE LEARNING. Reviewed. https://www.reviewed.com/parenting /features/student-workspace-essentials-online-learning

Supriyanto, A., Hartini, S., Irdasari, W. N., Miftahul, A., Oktapiana, S., \& Mumpuni, S. D. (2020). Teacher professional quality: Counselling services with technology in Pandemic Covid-19. Counsellia: Jurnal Bimbingan dan Konseling, 10(2), 176-189. http://doi.org/10.25273/counsellia.v10i2.7768 